\title{
PENGARUH HASIL BELAJAR MATEMATIKA SISWA DENGAN MENGUNAKAN MODEL PEMBELAJARAN EXAMPLE NON EXAMPLE DI SMP N 7 KOTA BENGKULU
}

\author{
Anisa Herawati ${ }^{1}$, Nurul Astuty Yensi B ${ }^{2}$, Rusdi ${ }^{3}$ \\ ${ }^{123}$ Program Studi Pendidikan Matematika JPMIPA FKIP Universitas Bengkulu \\ email : ${ }^{1}$ anisaherawati34@gmail.com, ${ }^{2}$ nurulastutyyensy@yahoo.com, ${ }^{3}$ rusdipendmat12@ gmail.com
}

\begin{abstract}
Abstrak
Penelitian ini bertujuan untuk mengetahui apakah ada perbedaan rata-rata hasil belajara matematika siswa dengan mengunakan model pembelajaran example non example dan model pembelajaran ekspositori di SMP Negeri 7 Kota Bengkulu. Populasi pada penelitian ini adalah siswa kelas VII SMP Negeri 7 Kota Bengkulu. Sampel penelitian ini adalah siswa kelas VII A sebagai kelas sampel 1 yang mengunakan model pemebalajan example non exampel dan Kelas VII H sebagai kelas sampel 2 dengan mengunakan model pembelajaran ekspositori. Teknik pengumpulan data dengan mengunakan instrument tes. Untuk analisis data mengunakan uji-t dengan data berdistribusi normal dan homogen. Nilai rata-rata kelas sampel 1 adalah 64,92 dan nialai rata-rata kelas sampel 2 yaitu 48,88. Berdasarkan hasil penelitian diperoleh rata-rata siswa yang diajar mengunakan Model Pembelajaran Exampel Non Exampel lebih tinggi dari pada rata-rata nilai siswa yang mengunakan model pembelajaran ekspositori. Hasil uji hipotesis diperoleh dengan mengunakan bantuan SPSS dengan yaitu Sig. (p-value) $=0,000<$ taraf signifikan $(\alpha)=0.05$ maka $\mathrm{H}_{0}$ ditolak. Sehingga dapat disimpulkan bahwa terdapat perbedaan rata-rata hasil belajar matematika siswa antara siswa yang mengunakan model pembelajaran example non example di kelas VII SMP Negeri 7 Kota Bengkulu.
\end{abstract}

Kata kunci : Hasil Belajar, Model Pembelajaran Example Non Example.

\begin{abstract}
This study aimed to determine whether there was a influence in the average learning outcomes of mathematics students using the model example non example in SMP Negeri 7 Bengkulu City. The population in this study was the seventh grade students of SMP Negeri 7 Kota Bengkulu. The sample of this research was the students of class VII A as a sample class 1 using model example of non exampel and Class VII H as sample 2 class by using expository learning model. Technique of collecting data was test instrument. For data analysis, used t-test with normal and homogeneous distributed data. The mean grade of sample 1 was 64.92 and the mean of sample 2 was 48.88 . Based on the result of the research, it was found that the average of students who were taught using Learning Model Exampel Non Exampel was higher than the average of the students who used the expository learning model. Hypothesis test results had obtained by using SPSS assistance with the Sig. (p-value) $=0,000<$ significant level $(\alpha)=0.05$ then H0 was rejected. Threfore, it can be concluded that there were differences in the average results of student learning mathematics influence students using non example example model in class VII SMP Negeri 7 Kota Bengkulu.
\end{abstract}

Keywords: Learning Outcomes, Exampel Non Exampel, Expository

\section{PENDAHULUAN}

Matematika merupakan cabang ilmu pengetahuan yang sangat diperlukan dalam segala bidang, seperti teknologi, kedokteran, politik, dan ekonomi. Sehingga matematika merupakan pelajaran yang wajib ada pada jenjang sekolah dasar sampai Perguruan Tinggi. Hal ini menunjukan bahwa matematika sangatlah penting untuk di pelajari dalam kehidupan. Hal tersebut sesuai dengan 
pernyataan Soedjadi (2000:99) yang menyatakan bahwa perkembangan matematika yang dapat dikatakan mendorong kemajuan teknologi serta mendorong untuk semakin cermat dalam menangkap fenomena yang terdapat dalam kehidupan sehari-hari manusia.

Hal ini disebabkan oleh beberapa faktor, seperti cara mengajar guru yang belum mendorong keaktifan siswa, belum tersedianya media pembelajaran dalam proses pembelajaran, masih belum terkontrolnya siswa-siswa dalam proses pembelajaran, kondisi kelas yang kurang menarik, dan jam pelajaran yang belum tepat untuk digunakan pada proses belajar matematika di kelas.

Salah satu model pembelajran yang dapat meningkatakan keaktifan yaitu model pembelajaran kooperatif, Menurut Johnson \& Johnson dalam Trianto (2009:57) tujuan pokok belajar kooperatif adalah memaksimalkan belajar siswa untuk peningkatan prestasi akademik dan pemahaman baik secara individu maupun secara kelompok. Salah satunya yaitu model example non example. Model pembelajaran ini menempatkan siswa-siswa ke dalam kelompok-kelompok kecil yang heterogen diaman materi disajikan dalam bentuk gambar ataupun diagram.

Berdasarkan wawancara oleh salah satu guru di SMPN 7 Kota Bengkulu dapat diketahui bahwa hasil belajar siswa masih tergolong rendah. Salah satunya di kelas VII A dengan rata-rata yaitu 47,09 sedangkan KKM di sekolah yaitu 68,00, hal ini menunjukan masih rendahnya hasil belajar di kelas tersebut.

Menurut Hudojo (2001:71) yang mengatakan bahwa belajar merupakan suatu proses aktif dalam memperoleh pengalaman atau pengetahuan baru sehingga menyebabkan perubahan tingkah laku. Sedangakan belajar menurut Syah (1995 : 89) adalah kegitan yang berproses dan merupakan unsur yang sangat fundamental dalam setiap penyelengaraan jenis dan jenjang pendidikan.

Untuk terjadinya proses belajar maka akan adanya proses pembelajran yang akan dilakukan terlebih dahulu. Pembelajarn iru sendiri yaitu suatu proses belajar antara guru dan peserta didik untuk mencapai suatu tujuan yang telah ditetapkan sebelumnya

Berdasarkan kajian tersebut penulis akhirnya melakukan penelitian dengan tujuan apakah terdapat pengaruh hasil belajar matematika siswa dengan mengunakan model pembelajaran example non example di SMP N 7 Kota Bengkulu pada kelas VII A.

Menurut Shoimin (2014:73) model example non example adalah pembelajaran yang membelajarkan murid terhadap permasalahan yang ada disekitarnya melalui analisis contoh-contoh berupa gambar-gambar, foto, dan kasus yang bermuat masalah. Pendapat lain dikemukakan oleh Yanuarto (2016:69) bahwa model pembelajaran example non example merupakan model pembelajaran yang menggunakan gambar sebagai media pembelajaran yang bertujuan mendorong siswa untuk belajar berpikir berpikir kritis dengan jalan memecahkan permasalahan-permasalahan yang terkandung dalam contoh-contoh permasalahan konsep yang disajikan.

Sedangakan menurut Lestari dan Yudhanegara (2015:76) example non example adalah metode yang mengajarkan siswa untuk belajar mengerti dan menganalisis sebuah konsep berdasarkan contoh dan bukan contoh dengan mengunakan media gambar yang bertujuan mendorong siswa untuk belajar berpikir kritis dengan jalan menyelesaikan permasalahan yang terkandung dalam contoh gambar yang disajikan.

Berdasarkan pengertian diatas, model pembelajaran example non example adalah suatu model pembelajaran kooperatif yang menerapkan pembelajaran contoh dan bukan contoh dengan berbatu sebuah gambar, sehingga siswa paham akan konsep materi yang diajarkan dengan penerapan penganalisisan konsep.

Adapun langkah-langkah model pebelajaran example non example :

\begin{tabular}{|c|c|}
\hline Fase & Langkah-langkah Pembelajaran \\
\hline Planning & $\begin{array}{l}\text { 1. Guru mempersiapkan gambar- } \\
\text { gambar sesuai dengan tujuan }\end{array}$ \\
\hline
\end{tabular}




\begin{tabular}{|c|c|}
\hline Fase & Langkah-langkah Pembelajaran \\
\hline & $\begin{array}{l}\text { pembelajaran. } \\
\text { 2. Membagi siswa kedalam } \\
\text { beberapa kelompok (kelompok } \\
\text { yang heterogen) }\end{array}$ \\
\hline $\begin{array}{l}\text { Giving } \\
\text { Picture }\end{array}$ & $\begin{array}{l}\text { Guru membagikan gambar-gambar } \\
\text { ke pada setiap kelompok }\end{array}$ \\
\hline $\begin{array}{l}\text { Analiyzing } \\
\text { Picture } \\
\text { (Discussion } \\
\text { ) }\end{array}$ & $\begin{array}{l}\text { Siswa menganalisis dari gambar- } \\
\text { gambar yang telah diberikan guru } \\
\text { untuk menentukan mana yang } \\
\text { benar (example) dan mana yang } \\
\text { salah (non example). }\end{array}$ \\
\hline $\begin{array}{l}\text { Presentatio } \\
n\end{array}$ & $\begin{array}{l}\text { Setiap kelompok mempresetasikan } \\
\text { hasil yang telah di analisis dan di } \\
\text { diskusikan oleh kelompoknya. }\end{array}$ \\
\hline Feeedback & $\begin{array}{l}\text { Guru memberikan penanaman } \\
\text { konsep yang benar dari peresentasi } \\
\text { yang telah dilakukan oleh masing- } \\
\text { masing kelompok. }\end{array}$ \\
\hline Conclusion & $\begin{array}{l}\text { Guru memberikan kesimpulan dan } \\
\text { rangkuman dari keseluruhan materi } \\
\text { yang diajarkan. }\end{array}$ \\
\hline
\end{tabular}

Sumber : modifikasi dari Taufik dan Muhammadi (2009).

Menurut Suprijino (2014:5) hasil belajar adalah pola-pola perbuatan, nilai-nilai, pengertian-pengertian, sikap-sikap, apresiasi dan keterampilan. Dari sisi siswa, hasil belajar merupakan puncak proses belajar. Hasil belajar tersebut dapat dibedakan menjadi dampak pengajaran dan dampak pengiring. Dampak pengajaran adalah hasil yang dapat diukur, sedangkan dampak pengiring adalah terapan pengetahuan dan kemampuan di bidang lain, sebagai suatu transfer belajar.

Berdasarkan pengertian diatas maka hasil belajar dapat dijelaskan dengan memahami dua kata yang membentuknya, yaitu "hasil" dan "belajar". Pengertian hasil (product) menunjukan pada suatu perolehan akibat dilakukannya suatu aktifitas atau proses yang mengakibatkan berubahnya input secara fungsional. Sedangkan belajar adalah dilakukan untuk mengusahakan adanya perubahan prilaku pada individu yang belajar. Perubahan prilaku tersebut merupakan yang menjadi hasil belajar. Jadi hasil belajar merupakan perubahan afektif, efektif ataupun psikomotorik akibat dari proses pembelajaran yang dilakukan.

\section{METODE}

Jenis penelitian yang diambil adalah penelitian eksperimen, metode penelitian eksperimen dapat diartikan sebagai metode penelitian yang digunakan untuk mencari pengaruh perlakuan tertentu terhadap yang lain dalam kondisi yang terkendali. Pada penelitian ini ada dua kelas sampel pertama (kelas eksperimen) mengunakan model pembelajaran dengan tipe example non example dan pada kelas sampel kedua (kelas kontrol) mengunakan pembelajran konvensional.

Penelitian ini adalah kuasi eksperimen, karena pemilihan sampel acaknya diabaikan, dimana kelas yang pertama menjadi kelas yang mendapat pembelajaran dengan menggunakan model pembelajaran kooperatif tipe example non example dan kelas kedua mendapat pembelajaran dengan menggunakan pembelajaran konvensional.

Populasi dalam penelitian ini adalah kelas VII di SMP N 7 Kota Bengkulu dengan sampel yang diambil yaitu kelas VII A dengan model pembelajaran example non example dan kelas VII H mengunakan pembelajaran konvensional. Intrumen yang digunakan yaitu berupa soal subyektif essay 7 soal yang akan diuji coba terlebih dahulu di kelas yang telah mempelajari materi yang akan di ajarkan pada kelas eksperimen. Selanjutnya intrumen tersebut di uji dengan validator, diamana peneliti mengambil validator satu orang dosen (Mela Aziza, S.Pd., M.Sc.) dan satu orang guru SMP N 7 Kota Bengkulu (Nuning,S.Pd.). Setelah di validasi oleh validator intrumen di uji coba pada kelas uji coba, untuk menguji validitas item tes digunakan rumus :

$$
\mathrm{r}_{\mathrm{xy}}=\frac{N \sum X Y-\left(\sum X\right) \cdot\left(\sum Y\right)}{\sqrt{N\left[\sum X^{2}-\left(\sum X\right)^{2}\right] \cdot\left[\sum Y^{2}-\left(\sum Y\right)^{2}\right]}}
$$


dimana dikatakan valid apabila :

$$
r_{x y}>r_{\text {tabel }}
$$

Reliabilitas

Untuk mengetahui apakah terdapar reliabilitas maka peneliti mengunakan rumus :

$$
\mathrm{r}=\left(\frac{n}{n-1}\right)\left(1-\frac{S i^{2}}{S_{t}^{2}}\right)
$$

Dengan

$$
\mathrm{S}_{\mathrm{i}}^{2}=\left(\frac{\sum X^{2}-\frac{\left(\sum X^{2}\right)}{N}}{N}\right)
$$

\begin{tabular}{|c|c|c|}
\hline $\begin{array}{c}\text { Koefisien } \\
\text { Korelasi }\end{array}$ & Korelasi & $\begin{array}{c}\text { Interprestasi } \\
\text { Reliabilitas }\end{array}$ \\
\hline $0,90 \leq \mathrm{r}<1,00$ & $\begin{array}{c}\text { Sangat } \\
\text { tinggi }\end{array}$ & $\begin{array}{c}\text { Sangat tetap/sangat } \\
\text { baik }\end{array}$ \\
\hline $0,70 \leq \mathrm{r}<0,90$ & Tinggi & Tetap / baik \\
\hline $0,40 \leq \mathrm{r}<0,70$ & Sedang & $\begin{array}{c}\text { Cukup tetap / cukup } \\
\text { baik }\end{array}$ \\
\hline $0,20 \leq \mathrm{r}<0,40$ & Rendah & Tidak tetap / buruk \\
\hline $\mathrm{r}<0,20$ & $\begin{array}{c}\text { Sangat } \\
\text { rendah }\end{array}$ & $\begin{array}{c}\text { Sangat tidak tetap/ } \\
\text { sangat buruk }\end{array}$ \\
\hline
\end{tabular}

dengan kriteria tinggi yaitu interval $0,70 \leq \mathrm{r}<$ 0,90 maka soal dapat dikatakn reliable.

Daya Beda Soal

$$
\mathrm{D}=\frac{\bar{X}_{A}-\bar{X}_{B}}{S M I}
$$

rumus diatas digunakan untuk mengetahui perbedaan dari soal-soal yang akan digun akan sebagai intrumen diaman soal memiliki daya beda apabila kriteria yang diadapat yaitu ketika DP $>0,40$.

\begin{tabular}{|c|c|}
\hline Nilai & $\begin{array}{c}\text { Interprestasi daya } \\
\text { Pembeda }\end{array}$ \\
\hline $0,70<\mathrm{DP} \leq 1,00$ & Sangat Baik \\
\hline $0,40<\mathrm{DP} \leq 0,70$ & Baik \\
\hline $0,20<\mathrm{DP} \leq 0,40$ & Cukup \\
\hline $0,00<\mathrm{DP} \leq 0,20$ & Buruk \\
\hline $\mathrm{DP} \leq 0,00$ & Sangat Buruk \\
\hline
\end{tabular}

Taraf Kesukaran Soal

$$
\mathrm{IK}=\frac{\bar{X}}{S M I}
$$

soal dapat digunakan apabila taraf kesukarnya yaitu pada interval $0,30<\mathrm{IK} \leq 0,30$.

\begin{tabular}{|c|c|}
\hline Indeks Kesukaran & Kriteria \\
\hline $\mathrm{IK}=0,00$ & Terlalu sukar \\
\hline $0,00<\mathrm{IK} \leq 0,30$ & Sukar \\
\hline $0,30<\mathrm{IK} \leq 0,70$ & Sedang \\
\hline $0,70<\mathrm{IK}<1,00$ & Mudah \\
\hline $\mathrm{IK}=1,00$ & Terlalu Mudah \\
\hline
\end{tabular}

Setelah intrumen di uji coba dan diperbaiki apabila tidak sesuai dengan kriteria selanjutnya intrumen di uji ke kelas ekperimen yang mengunakan model pembelajaran example non example dan di kelas yang belajar dengan pembelajaran konvesional. Setelah di lakukan posttest, selanjutnya hasil yang di dapat dilakukan tehnik analisis data yaitu dengan uji normalitas, uji homogenitas dan uji hipotesis.

\section{Uji Normalitas}

Untuk melihat apakah kedua data memiliki normalitas, peneliti melakukan pengolahan dengan bantuan SPSS mengunakan uji Chi Square dimana dikatakan normal apabila sig.> taraf nyata $(0,05)$.

\section{Uji Homogenitas}

Untuk uji homogenitas dapat dilakukan dengan bantuan SPSS dengan uji Levene Statistic, yang mana apabila sig. > taraf signigfikan $(0,05)$ maka dapat dikatakan kedua sampel homogen.

Uji Hipotesis

$\mathrm{t}=\frac{\bar{x}_{1}-\bar{x}_{2}}{\sqrt[S]{\frac{1}{n_{1}}+\frac{1}{n_{2}}}}$ dengan standar deviasi total: $\mathrm{S}=$ $\sqrt{\frac{\left(n_{1}-1\right) s_{1}^{2}+\left(n_{2}-1\right) s_{2}^{2}}{\left(n_{1}+n_{2}-2\right)}}$

Kriteria pengujian : $\mathrm{H}_{0}$ diterima jika $-\mathrm{t}_{\text {tabel }}<$ $t_{\text {hitung }}<\mathrm{t}_{\text {tabel }}$ dan $\mathrm{H}_{0}$ ditolak atau $\mathrm{H}_{1}$ diterima jika $t_{\text {hitung }} \leq-t_{\text {tabel }}$ atau $t_{\text {hitung }} \geq t_{\text {tabel }}$. Selain itu pengujian hipotesis juga dapat dilakukan mengunakan bantuan SPSS dengan uji-t. Dimana apabila sig.> taraf nyata maka $\mathrm{H}_{0}$ diterima, dan jika sig. $<$ taraf nyata maka $\mathrm{H}_{0}$ ditolak. 


\section{HASIL DAN PEMBAHASAN}

Penelitian di lakukan di SMP Negeri 7 Kota Bengkulu dari hari Selasa, 27 Maret 2018 sampai dengan Jumat,18 Mei 2018. Penelitian ini dilakukan sebanyak 14 kali pertemuan dimana 7 kali pertemuan di lakukan di kelas eksperimen 1 yaitu kelas VII A yang diberikan model pembelajaraan example non example. Dan 7 kali pertemuan di kelas eksperimen 2 yaitu kelas VII $\mathrm{H}$ yang mengunakan pembelajaran konvesional.

\section{Hasil Uji Coba Instrumen}

1. Uji Validitas

Uji validitas berdasarkan perhitungan dengan menggunakan rumus koefisien korelasi product moment $r_{\text {tabel }(N, \alpha)=} \mathrm{r}_{(29: 0,05)}=0,367$ dan kriteria koefisien korelasi validitas (table 3.4) maka hasil perhitungan uji validitas di dapat sebagai berikut :

Tabel 4.2. Hasil Perhitungan Validasi soal

\begin{tabular}{|c|c|c|c|}
\hline $\begin{array}{c}\text { Nomor } \\
\text { soal }\end{array}$ & Nilai $\mathbf{r}_{\mathbf{x y}}$ & Kriteria & Keterangan \\
\hline 1 & 0,27 & Rendah & Kurang Valid \\
\hline 2 & 0,84 & Tinggi & Valid \\
\hline 3 & 0,49 & Sedang & Valid \\
\hline 4 & 0,85 & Tinggi & Valid \\
\hline 5 & 0,76 & Tinggi & Valid \\
\hline 6 & 0,69 & Sedang & Valid \\
\hline 7 & 0,78 & Tinggi & Valid \\
\hline
\end{tabular}

2. Uji Reliabilitas

Uji reliabilitas berdasarkan hasil perhitungan (lampiran 21) di perolah bahwa nilai koefisien reliabilitas tes secara keseluruhan adalah 0,781. Jadi dapat disimpulkan bahwa koefisiean reliabilitas $=$ 0,80 atau berada pada $0,70<\mathrm{r}_{11}<0,90$ sehingga reliabilitas soal uji coba posttes berada pada kategori tinggi. Hal itu berarti bahwa intrumen soal termasuk reliabel (dapat dipercaya) atau konsisten.

\section{Uji Daya Beda Soal}

Hasil perhitungan setiap item butir soal daya pembeda didapat beberapa kriteria soal seperti pada tabel berikut ini :
Tabel 4.3 Daya Pembeda Soal

\begin{tabular}{|c|c|c|}
\hline Nomor Soal & $\begin{array}{c}\text { Daya } \\
\text { Pembeda }\end{array}$ & Kriteria \\
\hline 1 & 0,03 & Buruk \\
\hline 2 & 0,37 & Cukup \\
\hline 3 & 0,25 & Cukup \\
\hline 4 & 0,32 & Cukup \\
\hline 5 & 0,27 & Cukup \\
\hline 6 & 0,17 & Buruk \\
\hline 7 & 0,24 & Cukup \\
\hline
\end{tabular}

\section{Uji Kesukaran Soal}

Hasil perhitungan tingkat kesukaran didapat beberapa kriteria soal pada soal uji coba posttes sebagai berikut :

Tabel 4.4 Tingkat Kesukaran Soal Uji Coba

\begin{tabular}{|c|c|c|}
\hline $\begin{array}{c}\text { Nomor } \\
\text { Soal }\end{array}$ & $\begin{array}{c}\text { Tingkat } \\
\text { Kesukaran }\end{array}$ & Kriteria \\
\hline 1 & 0,64 & Sedang \\
\hline 2 & 0,44 & Sedang \\
\hline 3 & 0,35 & Sedang \\
\hline 4 & 0,30 & Sukar \\
\hline 5 & 0,30 & Sukar \\
\hline 6 & 0,29 & Sukar \\
\hline 7 & 0,22 & Sukar \\
\hline
\end{tabular}

Rekapitulasi hasil uji coba soal yang telah dilakukan validitas., reliabilitas, daya pembeda dan tingkat kesukaran soal dapat dilihat pada tabel diberikut ini:

Tabel 4.5 Rekapitulasi Hasil Uji Coba Soal

\begin{tabular}{|c|c|c|c|c|c|}
\hline $\begin{array}{c}\text { Nom } \\
\text { or } \\
\text { Soal }\end{array}$ & $\begin{array}{c}\text { Validit } \\
\text { as }\end{array}$ & $\begin{array}{c}\text { Reliabili } \\
\text { tas }\end{array}$ & $\begin{array}{c}\text { Daya } \\
\text { Pembe } \\
\text { da }\end{array}$ & $\begin{array}{c}\text { Tingkat } \\
\text { Kesukar } \\
\text { an }\end{array}$ & $\begin{array}{c}\text { Keteran } \\
\text { gan }\end{array}$ \\
\hline 1 & $\begin{array}{c}\text { Renda } \\
\mathrm{h}\end{array}$ & Reliabel & Buruk & Sedang & Direvisi \\
\hline 2 & Tinggi & Reliabel & Cukup & Sedang & $\begin{array}{c}\text { Digunaka } \\
\mathrm{n}\end{array}$ \\
\hline 3 & Sedang & Reliabel & Cukup & Sedang & $\begin{array}{c}\text { Digunaka } \\
\mathrm{n}\end{array}$ \\
\hline 4 & Tinggi & Reliabel & Cukup & Sukar & $\begin{array}{c}\text { Digunaka } \\
\mathrm{n}\end{array}$ \\
\hline 5 & Tinggi & Reliabel & Cukup & Sukar & $\begin{array}{c}\text { Digunaka } \\
\mathrm{n}\end{array}$ \\
\hline 6 & Sedang & Reliabel & Buruk & Sukar & Direvisi \\
\hline 7 & Tinggi & Reliabel & Cukup & Sukar & $\begin{array}{c}\text { Digunaka } \\
\mathrm{n}\end{array}$ \\
\hline
\end{tabular}

Berdasarkan tabel 4.5 dapat disimpulkan bahwa soal nomor 2,3,4,5,7 telah memenuhi keriteria sehingga soal dapat digunakan tanpa revisi. Pada soal nomor 1 memiliki kriteria 
validitas renah dan daya pembeda yang buruk sehingga soal perlu direvisi, begitu juga pada soal nomor 6 memiliki daya pembeda yang buruk sehongga soal perlu direvisi. Berdasarkan tabel 3.8 pada bab III, maka soal nomor 2,3,4,5, dan 7 merupakan soal yang digunkan tanpa di revisi, sedangkan soal nomor 1 dan 6 merupakan soal yang dapat digunakan namun perlu direvisi.

\section{Analisis Data}

1. Uji Normalitas

Tabel 4.7 Analisis Deskritif Hasil Belajar Siswa Kelas Eksperimen 1

\begin{tabular}{|l|c|}
\hline \multicolumn{1}{|c|}{ Deskriptif } & Nilai \\
\hline Jumlah Siswa & 30 \\
Jumlah Nilai Siswa & $1.912,5$ \\
Rata-rata & 63,750 \\
Nilai Tertinggi & 95 \\
Nilai Terendah & 32,5 \\
Standar Deviasi & 15,3655 \\
(SD) & 236,099 \\
Varians (S & 0,193 \\
Skewness & 62,5 \\
Median & 62,5 \\
Range & \\
\hline
\end{tabular}

Gambar 4.1 Hasil Belajar Siswa Kelas Eksperimen 1

Tabel 4.7 menunjukan bahwa kelas eksperimen 1 memiliki rata-rata hasil belajar 63,750 dari jumlah siswa 30 orang dan skewness yaitu 0,193 yang berarti nilai skewness positif namun nilai mendekati nilai nol $(-2<$ skewness $<2)$, maka data cenderung berdistribusi normal.
Tabel 4.8 Analisis Deskritif Hasil Belajar Siswa Kelas Ekperimen 2

\begin{tabular}{|l|c|}
\hline \multicolumn{1}{|c|}{ Deskriptif } & Nilai \\
\hline Jumlah Siswa & 29 \\
Jumlah Nilai Siswa & $1.412,5$ \\
Rata-rata & 48,707 \\
Nilai Tertinggi & 72,5 \\
Nilai Terendah & 15,0 \\
Standar Devisisasi & 13,1207 \\
(SD) & 172,152 \\
Varians (S & $-0,375$ \\
Skewness & 48,707 \\
Median & 57,5 \\
\hline & \\
\hline
\end{tabular}

Gambar 4.2 Hasil Belajar Siswa Kelas Ekperimen 2

Tabel 4.8 menunjukan bahwa kelas ekperimen 2 memiliki rata-rata hasil belajar 48,707 dari jumlah siswa 30 orang dan skewness yaitu $-0,375$ yang berarti nilai skewness negatif namun nilai mendekati nilai nol $(-2<$ skewness $<2)$, maka data cenderung berdistribusi normal.

Untuk normalitas secara kesulurhan didapat Data posttes pada penelitian ini adalah berdistribusi normal karena sig.>taraf signifikan $(\alpha)$ dengan hipotesis sebagai berikut :

$\mathrm{H}_{\mathrm{o}}$ : Data berdistribusi normal

$\mathrm{H}_{1}$ : Data tidak berdistribusi normal

Dari hasil perhitungan diperoleh bahwa hasil posstest pada penelitian menunjukan kedua kelas sampel memiliki nilai sig. ( $p$ value $)=0,623>$ taraf nyata $(\alpha)=0,05$ maka $\mathrm{H}_{0}$ diterima sehingga data atau nilai posttes kedua kelas berdistribusi normal.

Sama halnya apabila di coba secara manual, dimana didapat $X_{t}^{2}($ Chi Square tabel $)$ 
yaitu $=33,92$ sedangakan $X_{h}^{2}$ (Chi Square hitung ) yaitu $=19,356$, sehingga didapat bahwa $X_{h}^{2} \leq X_{t}^{2}$ sehingga dapat dikatakan bahwa distribusi data normal.

2. Uji Homogenitas

Sampel dapat dikatak homogen apabila nilai sig. $>$ taraf signifikan $(\alpha)$. Hasil pengujian SPSS homogenitas, sebagai berikut :

Tabel 4.9 Hasil Pengujian Homogenitas Kelas Sampel

\begin{tabular}{|c|c|}
\hline S1 & 57 \\
\hline S2 & 58 \\
\hline Fhitung & 0,882 \\
\hline Sig. & 0,352 \\
\hline
\end{tabular}

Sesuai pada tabel 4.9 menunjukan bahwa hasil posttest pada penelitian ini adalah sig $=$ 0,352 > taraf signifikan $(\alpha)=0,05$ maka dapat dikatakan kedua sampel (data) homogen. Sedangkan berdasarkan perhitungan $\mathrm{F}_{\text {tabel }}$ didapat $=4,03$ sedangankan $\mathrm{F}_{\text {hitung }}=0,882$, sehingga dapat diaktakan $F_{\text {tabel }}>F_{\text {hitung maka }}$ dapat dikatakan pula kedua sampel homogen.

3. Uji Hipotesis

Berdasarkan rata-rata hasil belajar siswa sebelum diberikan model pembelajaran example non example diperoleh 47,09 sedangkan setelah diberikan model pembelajarn example non example selama 6 pertemuan, rata-rata hasil belajar siswa kelas VIIA menjadi 63,75 . di lihat dari nilai rata-rata belajar sebelum mengunakan model pembelajaran exampel non exampel dan sesudah mengunakan model pembelajaran example non example terdapat peningkatan. Sedangkan diliat dari perhitungan SPSS bahwa hasil Asymp sig. $=0,000$ yang berarti secara statistik $\mathrm{H}_{0}$ ditolah atau terdapat pengaruh hasil belajar siswa antara sebelum dan setelah diberikan model pembelajaran example non example.

Hasil perhitungan pada diperoleh pengujian hipotesis dengan uji $t$ sebagai berikut:

Tabel 4.10 Hasil Uji t Posttest Kelas Sampel

\begin{tabular}{|l|l|l|}
\multicolumn{3}{c}{ Sampel } \\
\hline Cara & Nilai & Keterangan \\
\hline
\end{tabular}

\begin{tabular}{|c|c|c|c|}
\hline SPSS & $\begin{array}{c}\text { Sig. (2- } \\
\text { tailed) } \\
0,000\end{array}$ & $\begin{array}{c}\text { Taraf } \\
\text { sinifikan } \\
\end{array}$ & $\begin{array}{c}\mathrm{H}_{0} \text { ditolak sehingga } \mathrm{H}_{1} \\
\text { diterima }\end{array}$ \\
\hline Manual & $\mathrm{t}_{\text {hitung }}=$ & $\mathrm{t}_{\text {tabel }}=2,021$ & $\begin{array}{c}\mathrm{t}_{\text {hitung }}>\mathrm{t}_{\text {tabel }} \text { sehingga } \\
\text { dapat dikatakan } \mathrm{H} 0 \\
\text { ditolak dan } \mathrm{H} 1\end{array}$ \\
& 4,038 & & $\begin{array}{c}\text { diterima } \\
\end{array}$ \\
& & & \\
\hline
\end{tabular}

Berdasarkan tabel 4.10 diperoleh bahwa hasil pengujian posttest kelas eksperimen 1 dan kelas eksperimen 2 dengan nilai Sig. (p-value) $=0,000<$ taraf signifikan $(\alpha)=0.05$ maka $\mathrm{H}_{0}$ di tolak. Sehingga dapat disimpulkan bahwa terdapat pengaruh yang signifikan rata-rata hasil belajar matematika siswa antara siswa yang mengunakan model pembelajaran example non example di kelas VII A SMP Negeri 7 Kota Bengkulu.

Sedangkan secara manual didapat $t_{\text {hitung }}$ adalah $=4,038$ dan $t_{\text {tabel }}=2,021$ maka didapat $t_{\text {hitung }}>t_{\text {tabel }}$ sehingga dapat dikatakan $\mathrm{H}_{0}$ ditolak dan $\mathrm{H}_{1}$ diterima sama hal nya megunkan bantuan SPSS.

\section{PENUTUP}

\section{Simpulan}

Berdasarkan penelitian yang telah dilakukan pada siswa kelas VII A dan kelas VII $\mathrm{H}$ di SMP Negeri 7 Kota Bengkulu pada materi pengertian dan sifat-sifat dari bangun datar segiempat dan segitiga dapat disimpulkan adanya pengatuh yang signifikan pada rata-rata hasil belajar matematika siswa dengan mengunakan model pembelajaran exampel non exampel di SMP Negeri 7 Kota Bengkulu dengan nilai hasil perhitungan pengujuan hipotesis mengunkan uji t melalui SPSS adalah nilai Sig. $=0,000<$ taraf signifikan $(\alpha)=0,05$.

\section{Saran}

Berdasarkan hasil penelitian, saran yang dapat diberikan peneliti ialah :

1. Selalu mengingatkan dan mengecek peserta didik agar mengerjakan tahaptahap pada model pembelajaran yang digunakan terutama model pembelajran example non example. 
2. Selalu mengingatkan peserta didik untuk melibatkan semua anggota kelompok pada saat diskusi kelompok pada pemberajaran kooperatif example non example.

\section{DAFTAR PUSTAKA}

Emzir. 2007. Metodologi Penelitian Pendidikan. Jakarta : PT Raja Grafindo Persada.

Hudojo, Herman. 2001. Pengembangan Kurikulum dan Pembelajaran Matematika. Malang : IKIP Malang.

Lesatari, Karunia Eka dan Mokhamad Ridwan Yudhanegara. 2015. Penelitan Pendidikan Matematika. Bandung : PT Refika Aditama.

Shoimin,Aris. 2014. 68 Model Pembelajaran Inovatif dalam K13. Yogyakarta : ARRUZZ MEDIA
Soedjadi. 2000. Kiat Pendidikan Matematika di Indonesia. Jakarta : Direktorat Jendral Pendidikan Tinggi.

Sugiyono. 2008. Metode Penelitian Pendidikan. Bandung : Alfabeta.

Syah, Muhibbin. 1995. Psikologi Pendidikan dengan Pendekatan Baru. Bandung : Pt Remaja Rosdakarya.

Taufik, Taufina dan Muhammadi. 2009. Mozaik Pembelajaran Inovatif. Padang : SUKABINA Press

Trianto. 2009. Mendesain Model Pembelajaran Inovatif-Progresif. Surabaya : Pernada Media.

Yanuarto, Wanda Nugroho. 2016. Example Non -Example pada Pembelajaran Matematika. Edumatika Volume 06 Nomor 01 